\title{
Chapter 10 \\ Fathers Taking Leave Alone in the UK - A Gift Exchange Between Mother and Father?
}

\author{
Margaret O'Brien and Katherine Twamley
}

\subsection{Introduction}

The aim of this chapter is to examine the experiences of fathers taking leave alone in Britain, a relative late-comer amongst affluent countries to paid leave for fathers. British fathers were only given a legal right to take a 2 week paid paternity leave after the birth of a child in 2003, several decades after European neighbours (HM Employment Act 2002). Subsequently the possibility of taking more extended leave alone, partially paid, became possible through the introduction of Additional Paternity Leave (APL) in 2011. In this chapter we explore the phenomenon of fathers taking leave alone in Britain through insights from a small qualitative pilot study conducted with five couples where the fathers were taking APL. ${ }^{1}$ This study is one of the first to examine fathers' experiences on leave alone in the UK (Cornish 2013). Unlike projects reported in other chapters of this book, the project aimed to explore the couple context within which fathers take leave. This focus is particularly relevant in the UK setting where fathers' access to leave, beyond the 2 week postbirth paternity leave, is through a transfer from mother to father. In the chapter we focus on the findings concerning fathers' motivations, experiences and perceived consequences for work and family life. We suggest that the maternalist design of

\footnotetext{
${ }^{1}$ Twamley, K. Equality at home?: Exploring the experiences of couples where the father has taken additional paternity leave in the UK, Funded by the British Academy. Ref SG132666.

M. O’Brien (ه)

Thomas Coram Research Unit, University College London, London, United Kingdom e-mail: Margaret.obrien@ucl.ac.uk

K. Twamley

Social Science Research Unit, Department of Social Science, University College London, London, UK

e-mail: K.Twamley@ioe.ac.uk
} 
UK leave is an important policy context for couple negotiation and fathers' experiences of leave alone.

\subsection{The British Leave System for Fathers: Policy Context}

Leave provision for British fathers occupies a midway position between the generosity of Nordic Europe and its near absence in the United States. Over the last 40 years 'involved' fatherhood has become more embedded in the cultural, political and public discourses of the British fatherhood regime (Gregory and Milner 2008) although formal institutional support for involved fatherhood is rather weak. In terms of leave, the statutory provision is short or minimalist with low/no income replacement (O’Brien 2009).

The beginnings of the 'new father' rhetoric were observed in the 1980s, supported by first wave discoveries of male nurturance (e.g. Lamb 1976; McKee and O'Brien 1982), and now these views have become mainstream (Collier and Sheldon 2008; Gregory and Milner 2011). More recently, in response to the rise in dual earning families, the importance of female employment 'activation', and the political imperative of being 'modern and contemporary', political parties, left and right, rhetorically promote policies for a modern working family where parents share the care of children and fathers are engaged. The evidence showing an increase in British fathers' care time and reduction in paid work time suggests that a dichotomy between 'good provider' and 'active carer' is an inaccurate depiction of British fatherhood (Koslowski and Williams 2007; Smith Koslowski 2011) and that both practices are embedded in contemporary fathering. Indeed qualitative studies of fatherhood in Britain are most likely to portray diversity: commitment to the labour market can occur alongside expressive caring practices (Brannen et al. 2004) in a 'pick and mix' style (Yarwood 2011).

However, despite a political rhetoric of 'shared parenting' successive governments have adopted designs based on maternal transfer, which are known not to encourage paternal uptake (Moss and Deven 2006). There has been caution in restructuring or reforming parental leave architecture based on a post-war maternalist template of long, low paid maternity leave. The legacy of a long mother-centred leave has been resilient and to some extent has hindered design innovation in the UK. The government which introduced paternity leave in 2003 at the same time extended maternity leave even further from 9 to 12 months (HM 2002).

By the beginning of 2015, the statutory leave available for British fathers was: (1) Paternity Leave an individual entitlement, 2 weeks in duration after birth at a flat-rate payment of $£ 138.18$ (€160) a week, or $90 \%$ of average weekly earnings if that is less (HM Government 2015); (2) Parental Leave initiated in 1999 as part of the EU Parental Leave Directive, an individual entitlement, 18 weeks, unpaid, up to the child's fifth birthday, with a maximum of 4 weeks leave to be taken in any one calendar year; (3) Additional Paternity Leave, introduced in 2010 (and implemented in April 2011), an option for mothers to transfer part of the 52 weeks maternity leave 
entitlement to the father/ partner from 20 weeks after the birth or adoption of a child. Fathers taking APL can have access to the maternity pay entitlement relabelled Additional Statutory Paternity Pay (ASPP), which by 20 weeks is flat rate and available only until 39 weeks as week 40-52 statutory maternity leave is unpaid (O'Brien et al. 2014). (4) Shared Parental Leave a new provision since April 2015 with a similar maternal transfer design as APL but enabling the transfer to occur from 2 weeks rather than 20 weeks after birth (4 weeks for manual workers), and offering more flexibility in use than APL .

The Additional Paternity Leave legislation provided the national policy setting for the fathers in this study who were interviewed during 2013 and 2014. Their leave from employment was not an individual entitlement or right but instead a provision mediated at their partner's discretion and her formal eligibility ..$^{2}$ In addition, fathers accessing APL were also subject to the national eligibility criteria, relevant for paternity leave too, that: they are the biological father of the child or the mother's husband, partner or civil partner; they expect to have responsibility for the child's upbringing; they have worked continuously for their employer for 26 weeks ending with the fifteenth week before the baby is due and remain employed at the time of the child's birth.

In addition APL fathers needed to give 8 weeks' notification of their wish to take APL to employers. The conditionality of continuous and secure employment assumes a degree of permanency and clearly excludes the growing number of British fathers working in precarious employment situations such as 'zero-hour' and temporary contracts (ONS 2015). Notably all but one of the fathers and partners of the current study are in professional secure occupations.

\subsection{What Is Known About British Fathers Taking Leave Alone?}

Although government ministers acclaimed both APL and SPL legislation as innovations to enhance fathers' engagement in the first year of children's lives - 'This [APL] enables fathers to play a bigger part in bringing up their children' (Guardian 2010) - backstage civil servant predictions were less optimistic. The formal regulatory impact assessment was that uptake would be low - 4-8\% of eligible fathers (HM 2010). Subsequent estimates of APL uptake were even lower. Data released by

\footnotetext{
${ }^{2}$ All women employees are eligible for 26 weeks 'Ordinary Maternity Leave' (OML) plus a further 26 weeks of 'Additional Maternity Leave' (AML). Women employees who have worked for their employer continuously for 26 weeks, up to the fifteenth week before the week the baby is due, and who meet a minimum earnings test, are eligible for 'Statutory Maternity Pay' (SMP) consisting of six weeks' payment at $90 \%$ of average gross weekly earnings, with no ceiling, plus 33 weeks of flat-rate payment at $£ 138.18$ (O’Brien et al. 2014).
} 
the Department for Business, Innovation and Skills ${ }^{3}$ report less than $1 \%$ in $2011-$ 2012, and around $1.4 \%$ of eligible men between 2012 and 2013. These figures are based on an estimation of the numbers of employers who claim back statutory payments for fathers taking APL as there is no formal recording of leave uptake by fathers or mothers in the UK, unlike in other European countries (Moss 2014). Not all employers claim back statutory pay, however, and if fathers take leave after 9 months they are not entitled to any statutory pay, so these estimates are likely an underestimation, though nonetheless indicative of the low take-up.

Studies profiling the characteristics or experiences of fathers taking APL are rare in the UK. Formally they must meet the eligibility criteria as outlined above. A survey of UK doctors found that while a majority took paternity leave, only $3 \%$ reported taking APL (Gordon and Szram 2013). Similarly national evidence shows that by the end of the decade over $90 \%$ of fathers take some time off work after childbirth (Chanfreau et al. 2011). Those taking paternity leave were most likely to take the statutory 2 weeks (50\%), but $34 \%$ took less than 2 weeks, and $16 \%$ took more than 2 weeks. The odds of taking paternity leave were significantly higher for men working in the public sector and other workplaces where there were familyfriendly arrangements. As shown in other countries, local workplace norms can facilitate or hinder fathers taking statutory paternity leave or any leave after childbirth (Haas et al. 2002). Where there were no family-friendly arrangements available, the take-up of time off work following the birth was lowest (only $88 \%$ of fathers took time off compared with $93 \%$ taking time off where there were between one or two family-friendly arrangements available). In a UK qualitative study of fathers' experience of working flexibly, Gatrell et al. (2014) show how British fathers can feel marginalized from the possibilities of flexible work if line managers focus only on their economic provider roles. Similarly UK doctors who did not take up APL reported concerns about impact on career progression and workplace reasons but the fathers also mentioned impracticalities of the law, and poor awareness (Gordon and Szram 2013).

\subsection{Theoretical and Methodological Framework}

The overall aim of the study was to explore the intersections of intimacy, gender and equality, through research with couples where both partners take leave alone in the first year after the birth of a child. The study drew on the proposition that intimacy is a mediating factor in couples' gender roles, based on research with couples which found that women were willing to ignore instances of inequality if they felt 'loved' (Jamieson 2012; Twamley 2012) and other research which has shown that intimacy and intimate relationships shape a couple's ability to co-parent (Cowan and Cowan 2000). In line with the overall aim of this book, we will focus in this chapter on

\footnotetext{
${ }^{3} \mathrm{http}: / / \mathrm{www}$. publications.parliament.uk/pa/cm201314/cmhansrd/cm140403/text/140403w0001. htm
} 
fathers' motivations and experiences of taking leave - with data from mothers supplementing fathers' data where relevant.

The main theoretical framework informing the analysis presented here is that cultural constructions of gender shape parents' behaviour and ability to parent differently. In the UK there are highly gendered models of appropriate care, despite shared parenting rhetoric. In this paper we examine how parents understand their particular division of leave in relation to these models of parenting. Undertaking this chapter has also led us to examine how policy shapes behaviour, and we have therefore examined the ways in which the current policy framing and context has influenced participants' motivations and experiences of fathers' leave taken alone.

\subsubsection{Methods and Sample}

The full study used multiple data collection methods with both members of the couple in an effort to unpack how the intimate relationship acts as a mediating factor in parents' gender roles and parenting practices during leave. Drawing on data from both members of the couple also elucidates the negotiations and tensions between mother and father in resolving their parenting roles (see Pahl 1989; McKay and Doucet 2010). Participants were interviewed first with their partner present and then separately; each participant kept a reflective diary for a week during the father's $\mathrm{APL}^{4}$; and each father and one mother ${ }^{5}$ was observed for a half day during their leave. The couple interviews explored the collective constructed story of APL, while the separate interviews allowed a more in-depth focus on each individual's experience. Participants were broadly asked to discuss their pregnancy, birth, early leavetaking experiences, motivation to take APL, and their overall experiences in the first year since the birth of their child. Research diaries were requested from the participants to elicit issues that are potentially more difficult to discuss in person, such as disagreements between spouses and emotional responses, as well as for eliciting activities that the participants may see as insignificant, taken for granted, or which they are likely to forget, for instance regular and mundane activities of care (Gabb 2008). The observations had two functions: firstly, to build trust and rapport between the parents and the researcher, and secondly, to observe practices of care and the relationship between the parents and their children.

All the interviews, diaries and fieldnotes were fully transcribed and analysed using the NVivo computer programme, version ten (QSR International 2012). The analysis broadly followed the methods of constructivist grounded theory, as outlined by Charmaz (2006). In this chapter we draw primarily on the interview material and observations.

\footnotetext{
${ }^{4}$ One participant (Kylie) never submitted a diary. All names are pseudonyms to preserve confidentiality.

${ }^{5}$ Only one woman was observed on leave as all the other couples were recruited after the men had started their leave, by which time the women had returned to work.
} 
The couples were recruited in a variety of ways: Three women responded to a post on a UK parent forum called 'Mumsnet'; one father was contacted via a local fathers' group in London; and one father was contacted via his online blog (where he was discussing his experiences of APL). Anonymity and confidentiality were assured to each participant (pseudonyms are used throughout this paper) and informed consent was sought before commencing data collection.

Table 10.1 shows the characteristics of the couples included in the study. They are all white, first-time parents, in their 30s or above, and have a university education. Couple income levels vary quite substantially across the sample, however, in all couples the man and woman earn similar amounts or the woman earns more. Three couples are from the UK, one couple were from mainland Europe, and one from Australia.

In terms of their leave-taking patterns, in three couples the woman took more leave than the man, in one couple they shared equally the leave, and in the remaining couple they shared the official leave period equally, but then the father took an extra 3 months of leave without pay on top of his APL. APL is only available to the father from 5 months ( 20 weeks) after the birth until the child turns 1 year, thus in terms of timing and sequencing generally mothers were the main carer of the child during the first 5-6 months, once fathers returned to employment after the initial 2 week paternity leave. However, one father, Simon, started leave at 4 months when his wife returned to work. He used a combination of annual leave and parental leave until his APL started. The fathers received statutory pay if they started their leave before 9 months. None received enhanced benefits from work during APL.

\subsection{Findings}

\subsubsection{Motivations and Decisions to Take Leave}

The participants cited multiple motivations to use APL, but primarily they reported that sharing leave was 'fairer', since both parents could share the 'joy' of parenting, the difficulties of full-time care, and the expectant career penalty of extended leave. Here Simon speaks about how it came about that he took APL, in his couple interview:

[...] I think it was the woman taking a year out of her career is like quite, it has other effects other than just not being paid for a year, and how like three months is far less bad. But I think we agreed that between us - three months, if you take three months off it's not quite as bad and that therefore, seeing as we do the same job, I could take three months off and we'd be back in the same boat and that would be fine. Simon, Lawyer, 35 (3 months leave)

For Simon, parity in repercussions and responsibilities of childcare were the most important factors in deciding to take leave. They chose to both take 3 months after reading the book 'Shattered' (Asher 2012) which cited research that 3 months of leave has a negligible impact on a career. APL is only available from 20 weeks, so 


\begin{tabular}{|c|c|c|c|c|c|c|c|c|c|c|}
\hline 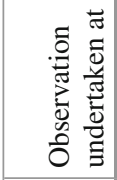 & & 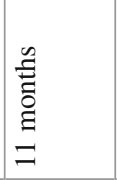 & $\begin{array}{l}\mathscr{n} \\
\stackrel{E}{\Xi} \\
\vdots \\
\Xi \\
=\end{array}$ & & & $\underset{\mathfrak{E}}{\stackrel{\mathscr{E}}{\Xi}}$ & 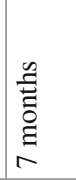 & $\begin{array}{l}n \\
\Xi \\
\vdots \\
\vdots \\
\vdots \\
a\end{array}$ & & 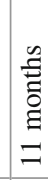 \\
\hline 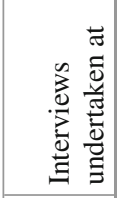 & 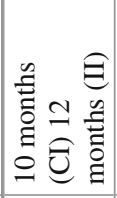 & 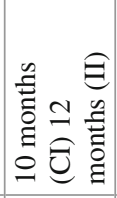 & 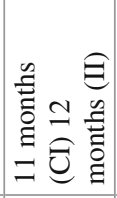 & 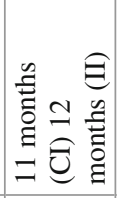 & 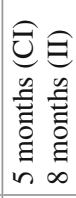 & 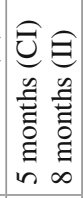 & 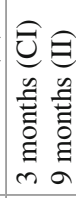 & $\begin{array}{l}\Theta \\
0 \\
\tilde{E} \\
0 \\
0 \\
\vdots \\
0\end{array}$ & 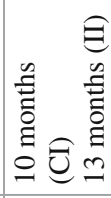 & 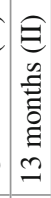 \\
\hline 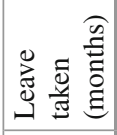 & 0 & $\begin{array}{l}m \\
+ \\
0\end{array}$ & 0 & 0 & $\nabla$ & $m$ & $\infty$ & $\nabla$ & $a$ & $m$ \\
\hline $\begin{array}{l}\vec{E} \\
\stackrel{\vec{J}}{\tilde{N}} \\
\text { is }\end{array}$ & $\begin{array}{l}8 \\
8 \\
8 \\
\frac{8}{1} \\
6 \\
4 \\
4\end{array}$ & $\begin{array}{l}8 \\
8 \\
0 \\
\frac{1}{1} \\
\oplus \\
4\end{array}$ & $\begin{array}{l}8 \\
8 \\
0 \\
0 \\
4 \\
\dot{4}\end{array}$ & $\begin{array}{l}8 \\
8 \\
0 \\
0 \\
0 \\
0 \\
01 \\
4\end{array}$ & $\begin{array}{l}8 \\
8 \\
8 \\
8 \\
1 \\
0 \\
4 \\
4\end{array}$ & $\begin{array}{l}8 \\
8 \\
0 \\
8 \\
1 \\
1 \\
0 \\
4 \\
4\end{array}$ & $\begin{array}{l}8 \\
8 \\
8 \\
8 \\
1 \\
\dot{1} \\
4\end{array}$ & 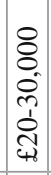 & $\begin{array}{l}8 \\
8 \\
8 \\
\dot{9} \\
\dot{1} \\
4 \\
4\end{array}$ & $\begin{array}{l}8 \\
8 \\
8 \\
0 \\
1 \\
7 \\
4\end{array}$ \\
\hline 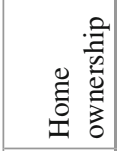 & 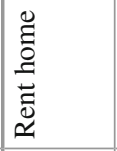 & 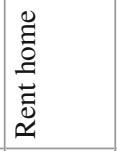 & 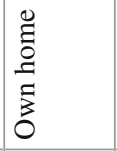 & 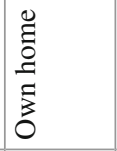 & 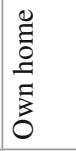 & 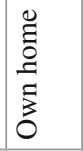 & 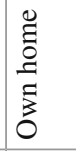 & 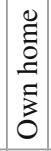 & 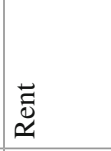 & $\begin{array}{l}\overrightarrow{\tilde{D}} \\
\stackrel{\underline{x}}{ }\end{array}$ \\
\hline 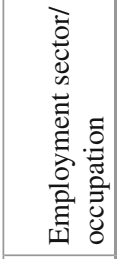 & 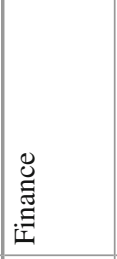 & 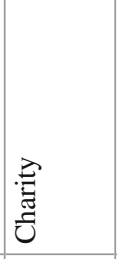 & 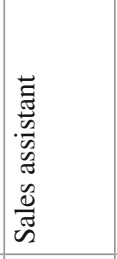 & 青 & 离 & 离 & 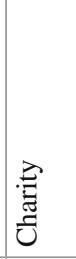 & :己 & 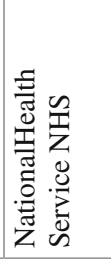 & 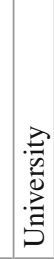 \\
\hline 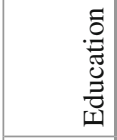 & 吕 & 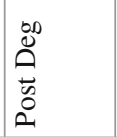 & $\underset{\infty}{\mathbb{1}}$ & 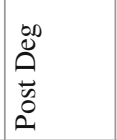 & 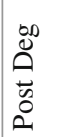 & $\begin{array}{l}0 \\
0 \\
0 \\
0 \\
\tilde{n} \\
0 \\
0\end{array}$ & 占 & 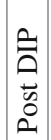 & $\begin{array}{l}0 \\
0 \\
0 \\
0 \\
0 \\
0 \\
0\end{array}$ & $\frac{\partial}{2}$ \\
\hline$\underset{<}{\infty}$ & ले & ले & $\bar{m}$ & $\bar{m}$ & $m$ & $\ddot{n}$ & $m$ & 于 & $\bar{m}$ & $m$ \\
\hline 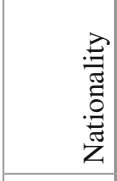 & 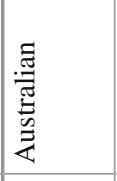 & 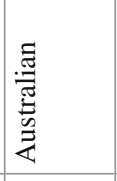 & 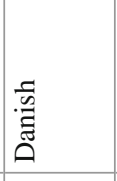 & $\begin{array}{l}\tilde{U} \\
\stackrel{N}{N} \\
\mathcal{U}\end{array}$ & 兑 & 氮 & 栉 & 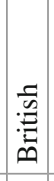 & 㺼 & 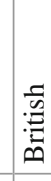 \\
\hline $\begin{array}{c}\stackrel{\Xi}{\Xi} \\
\stackrel{\Xi}{Z}\end{array}$ & 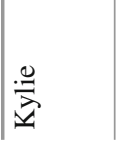 & 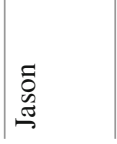 & $\frac{\bar{u}}{0}$ & $\frac{\pi}{\tilde{Z}}$ & ڤ్ర & 音 & 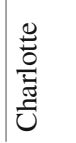 & 胥 & $\begin{array}{l}.0 \\
1 \\
11\end{array}$ & 픙 \\
\hline
\end{tabular}


Simon took annual leave and unpaid parental leave until the baby was 20 weeks, when he started APL.

Jason, Arthur and Peter, placed more emphasis on the 'fairness' of both parents having a leave period to develop a bond with the baby. These men were highly engaged in a discourse of 'involved' fatherhood. For example, when Jason and Kylie were asked how it is they came to be taking APL, Jason responds:

I think I mean before even considering having children, we had always, without agreeing anything, thought that we'd share the [maternity] leave. Probably one for just to be equitable between the two of us, and where we were, we just make it work, whether it was financially supported by the government or not. But I also always wanted to be a stay-at-home dad at some stage. Jason, Charity worker, 34 ( 9 months leave)

While Kylie puts a slightly different emphasis in her narrative about their motivations to use APL, she agrees that Jason is more 'naturally' a better fit as a carer, since he enjoys children so much. Jason also reports that Kylie is the more ambitious one in the couple. In addition to 6 months of APL, Jason took 3 months of unpaid leave from work and reduced his working hours to 3 days a week after he returned to work. As he mentions above, he would ultimately like to be a full-time stay-at-home Dad, if their finances allow it. No other father expressed such a desire. Arthur, for example, who also placed an emphasis on leave as a valuable experience to share time with his child, felt that taking leave alone for a period of time would ensure that he was an equal parent with his wife.

The timing of the interview, however, is important in interpreting participants' motivations to take leave. In his first interview with his wife Evie, John initially said that APL was fairer because both parents would share the responsibility and difficulties of full-time care. John and Evie reported a difficult transition to parenting as their daughter was hospitalized for the first 2 weeks of her life. At the time of the interviews they were moving home to another city and both changing jobs, which created further stresses in their lives and they felt made their experiences of leave more difficult. Upon reflection, however, John (and Evie) in his later individual interview and observation recalled that their initial motivations had been to share the 'special time' with their daughter that is afforded by an extended leave period. Their particularly stressful leave periods had coloured their view of leave so that it became more about sharing the 'burden' of care. All in all, however, fathers described taking APL, in one way or another, as 'fair' and more 'equal', which was, for different reasons, an important aspect of their relationships with their wives or partners.

\subsubsection{Financial and Work Considerations in the Decision to Take Leave}

The time when men are able to take APL they can receive either a small stipend ( $£ 138.18$ weekly), or no remuneration at all (depending on what weeks are taken). While on average men in the UK tend to earn more than women (World Economic Forum 2014) and therefore a man taking leave is usually more costly to the couple 
in forgone income, couples in this study earned similar salaries or the woman earned more. All participants reported that this facilitated their ability to take up APL. Anka and Peter, for example stated:

Anka: And also I think the financial factor was also quite important in our situation, because I know that many families probably couldn't afford dad staying at home because sometimes men still earn much more than women. [...] That's really not sustainable for the family, so in our situation, we are very similar incomes. It didn't really matter if it was my income that dropped or his.

Peter: Because it would've dropped anyway. There's no difference.

Anka, Administrator, 31 (6 months leave) and Peter, Sales Assistant, 31 (6 months leave)

For Simon and Dora, the fact that they have similar jobs and earn the same amount was pivotal in their decision to use APL and in the overall narrative of their relationship and parenting. They explain that this 'fact' of equality means that there are no 'obvious answers' as to who should do what in terms of care and housework. Simon says:

Because we had this fairly special position of us both having similar jobs and similar incomes, that it's not entirely clear who should do the laundry, who should make dinner. Or who should organize for the carpenters to come and quote for the stairs. Simon, Lawyer, 35 (3 months leave)

They frequently referred to their work parity throughout their interviews. This explicit and repeated reference to similar earnings was unusual amongst the couples, who generally drew on a notion of 'fairness' as a part of an intimate partnership, rather than based on similar earnings/work responsibilities. Even so, it is significant (even in a small sample) that in none of the couples the man earned more than the woman, and perhaps points to the worth afforded a woman's career based on her earnings, as well as the overall 'cost' of men taking leave.

Where the woman earned more than the man - in the cases of Charlotte and Arthur and Kylie and Jason - the couples were adamant that this had not been the basis of their decision to use APL, but had merely facilitated the affordability of leave-taking. The adamancy apparent in their accounts, appeared to stem from an uncomfortable assumption that the men may be judged to have been 'forced' to take leave by a more domineering and higher earning wife. For example, Kylie said

So I'm quite conscious with our friends not to position it as the financial aspect of the next phase - because I wouldn't want people to think that he was some kind of, of being, I don't know, doing it because he wasn't earning as much money. And that, so that was kind of lumped on him or anything else. Kylie, Finance, 34 (6 months leave, partner took 9 months)

In contrast, when asked how she feels about people reacting to her working fulltime and/or returning 'early' to work after the birth of her child, Kylie said she had no problems with people seeing her in this way. Kylie's account should be situated in the normative pattern for the majority (89\%) of UK mothers taking 39 of the 52 weeks of leave offered (Chanfreau et al. 2011). It appears then that so-called 'masculine' traits in a woman - such as ambition and career-orientation - were acceptable, but more 'feminine' traits in a man - such as caring and home oriented - were perceived as less acceptable, at least to couples in this study. 


\subsubsection{Additional Paternity Leave Policy and Context}

The study also revealed how gendered norms and the particular policy constraints (which are in turn shaped by gendered norms) shape couples' negotiations around leave. Specifically, men's uptake of APL is constructed in the couple narratives as his individual choice, rather than a negotiated couple decision. In couple interviews, women report presenting APL as an option to their partners, for which some noted a corresponding gratitude for the offer:

Anka: I wanted to give my husband a chance to experience how it is to stay at home with a little baby. Anka, Administrator, 31 (6 months leave, partner took 6 months)

Interviewer: You mentioned that you thought Dora felt a little bit conflicted -- did you ever feel a bit conflicted about her going back to work and you...?

Simon: Not really, I felt quite fortunate that she was wanting to go back to work and willing to let me take time off. Simon, Lawyer, 35 (3 months leave)

In response to this 'offer' of leave, the men refer to the aforementioned 'fairness' of accepting to take leave to share the career penalty and/or the care responsibility of a new baby. Women reiterate statements such as 'I left it up to him' and 'it was completely his decision', possibly in a bid to show his willingness in taking leave and perhaps to preserve notions of 'masculinity'. Women also reported that they would have been content to take the full leave if he had not accepted to take APL, since they did not like the idea of their child being in daycare before the age of 9 months or 1 year (depending on the couple). The exception is Dora and Simon where Dora reported intending to employ a nanny if her husband did not take up APL.

The policy context - as a transfer of maternity leave from the mother to the father when she returns to work - clearly contributes to this narrative, since the leave is constructed as 'properly' hers, albeit with the possibility of transferral. The result is that women report 'gratitude' and pride in their partners for taking leave and spoke of him as a kind of role model to his peers which they hoped would 'normalize' the practice. For example, Anka said:

I actually felt quite proud [unclear 00:11:55] when we decided. I remember sometimes my friends $[\ldots]$ on Facebook, for example. I saw one photo that "Oh like men think that maternity leave is [a holiday]..." [...] and there were lots of comments like "yeah, men don't know when they come home and they expect everything to be ready, clean and baby's fed and sleep. It's not so easy." I could then write like "Yeah my husband actually knows something about that." [...] And there was like a discussion that every man should try it and see so they then understand that it's not as easy as they think. It's not a holiday. Anka, Administrator, 31 (6 months leave, husband took 6 months)

Implicit in this account is a clear inequality in public perceptions of leave-taking by men and women: In this context where it is so rare for men to take leave alone, women were never, nor are in general, 'commended' for taking leave, nor for looking after their child. The pride and gratitude reported by women in their partners makes sense within the context perhaps, but also serves to reinforce the "naturalness' of women taking primary responsibility for young children, even as these couples were trying to challenge gendered parenting norms. 
This relational exchange between the couple around leave, is akin to Hochschild's writings on the 'gift economy' of couples. Hochschild (2003) explains that in a two working household, a man may feel that his small contribution to taking care of the house is actually much more than either the average man does, or than what his father did. He therefore sees his household work as an 'extra' contribution and so a 'gift' to his wife, and feels he can legitimately expect gratitude from his wife. Concordance in the understanding of 'gifting' is important to maintain a relationship since, as Hochschild says, 'the sense of a genuine giving and receiving is a part of love' (2003:105). The couples in this study appear to be configuring APL as a gift exchange: the woman 'gives' her husband the opportunity to take APL, and he 'gifts' her father involvement by taking it.

This understanding of gifting leave does not counteract gendered parenting roles, but rather reinforces them. It emanates both from the structure of the leave as 'transferable' from the mother to her partner, and from the broader context where men taking leave is unusual. However, as Hochschild argues, 'changes in the broader culture also shift the many tiny mental baselines that undergird a person's sense of a gift' (Hochschild 2003:104). And this was evident in the couples' narratives. So they both formulated the leave as a gift exchange, and challenged their own constructions of this gift exchange. For example, after being asked whether she and her husband John would consider taking APL again if they had another child, Evie said 'it's completely up to John to decide', to which John responded that he would be happy to take APL again. This discussion was returned to in the individual interview with Evie:

Interviewer: How would you have felt if he didn't want to (take APL again)?

Evie: I think that would have been quite challenging. I'd have found that quite tricky because .. I guess - yeah, I don't know. I think I would have respected that more with him having done it, than if he was just like "no I'm not doing that", without discussion or without having had the experience. But at the same time, if it's something that I would be doing - I guess it would depend on his reasons actually. If it was just that actually it's not very fun [laughs] and I don't want to do it, so you can just do it, I don't think I'd find that very fair - coming back to fairness again. [laughs] But I don't know - I can't really think of a good reason why I would, when I would maybe be more accepting.

Evie, Health therapist, 31 ( 9 months leave, partner took 3 months)

So we can see that Evie constructed the leave transfer as 'up to John' in the couple interview, but in the individual interview struggled to find a valid reason for him not accepting his leave - 'her gift'. She said, "I wanted him to take it because he wanted to but I would have found it very difficult if he hadn't wanted to."

\subsubsection{Fathers' Experiences of APL}

\section{Tiring and Hard Work}

Observations of fathers on leave demonstrate the routine and repetitive nature of life with a new baby, whatever the sex of the carer. The most time and effort was spent on feeding and encouraging babies to sleep, with fathers entering into long and detailed conversations about the various whims and particularities of their babies, 
along with how they attempted to arrange some order on the day, while also following their child's lead. For example, the following is an extract from an observation with Jason:

Jason says his daily dilemma is whether he should let [son] sleep or wake him for an activity? He knows [son] will enjoy the activity, but then he needs his sleep too and maybe he will be unhappy if woken up. (This conversation went on for several minutes.) Jason, Charity worker, 34 (9 months leave)

Another father, John, expressed multiple difficulties with his young baby, who refused to sleep in her cot during the day and in fact would only sleep while carried in the sling as he walked. Indeed, on the day of the observation session, John spent almost the entire period with his daughter in his arms. Upon arrival he was already putting on the sling to leave the house as it was approaching his daughter's nap time. After walking around almost 2 hours while the baby slept in the sling, he stopped for lunch in a café when she woke, played in the playground with her, and then walked for another 2 hours while she sang and eventually fell asleep again. John never actually had any 'down time' during this observation period and from his reports very little during his leave alone with his daughter, since for every nap he was walking around, and while the baby was awake she demanded attention. John described feeling severe fatigue while on leave, feelings of frustration and, particularly at the beginning of his leave, of incapability. Another mother also described how her husband had become unexpectedly sensitive while on leave, not allowing any discussions on his care practices which she felt was down to his feelings of incompetency.

Fathers were also observed shopping for groceries, washing laundry, baking and cleaning. Nonetheless, the couples reported some disagreements over the amount of housework fathers did while on leave. In general, women felt that men accomplished less than they had while they were on leave - such as cleaning the house or shopping for groceries. In most cases this was resolved, either by the men increasing their housework load, or by the women reducing their expectations (in response to arguments from their husbands that there is less available time when the babies are above 6 months old). In one case, with Peter and Anka, these disagreements were never really resolved. This impasse appeared to be because Peter's main motivation to take leave was to build a stronger relationship with his son, and potentially his association with housecleaning as less 'masculine' than involved fathering. He repeatedly joked 'I am a good father but I am not a good househusband!' In this case, APL appeared to lead to more co-parenting, but not necessarily more equality overall in the division of household labour.

In addition to housework, fathers were observed participating in a range of caring activities with the baby, at home (for example, reading and playing) and outside the household, (including, swimming classes, musical groups, parent and baby rhyme time events and local playground visits). Fathers enjoyed these activities, but also expressed boredom at times and described the leave period as more difficult than anticipated, with far less 'personal' time than they had hoped. All fathers reported feeling 'ready' to return to work once their leave came to an end, except for Jason who extended his leave by an extra 3 months by requesting unpaid leave from his workplace. He also dropped down to part-time hours once he returned to work. 


\section{Isolating Experience}

Participants' experiences of leave were strongly influenced by the unusualness of APL in the UK context. Fathers reported having few or no friends with whom to share their leave experience, and frequently contrasted their experiences with that of their wives/partners, who broadly speaking had a far wider and closer circle of friends while on leave. ${ }^{6}$ This context led some men to express feelings of isolation, as Peter reflected during an observation session:

Peter chats while the TV is on. Says he feels lonely sometimes as there are no other men. He's approached men at 'Rhyme Time', ${ }^{7}$ none were on APL. Also tried to form a Dads' group with other men from work, none of whom took APL. Says he was first in his company. Peter, Sales assistant, 31 (6 months leave)

None of the men ever met any other man on APL during their leave period. Typically they were the only man present with a baby in public places during observations. When other men with babies were observed, for example at a parent and baby session, participants had normally already approached them to find they either worked from home 1 day a week or part-time / evenings, in order to bring the child to that particular event.

There were, of course, plenty of mothers on leave. Previous research conducted in the US (Rochlen et al. 2010) with 88 stay-at-home fathers found that $40 \%$ of the participants reported experience of role-related stigma, with $70 \%$ attributing that to stay-at-home mothers, and a large number experiencing stigma in playground settings. Fathers in this study reported some mixed reactions but in general a positive response from mothers at 'parent and baby' groups, but as Jason says,

what you don't get is the "let's go for a coffee, let's go and have lunch", as much. They're happy to talk to you, and that sort of thing, which is lovely, but it's that sort of next step in the friendship or whatever it might be doesn't come . come as easy..' Jason, Charity worker, 34 ( 9 months leave)

While Jason felt excluded due to his sex, other men reported self-excluding themselves from potential female friendships: Arthur reported not wanting to hang out with other mothers on leave, as he felt it would be 'too complicated' with the potential sexual undertones created by such an intimacy. In order to avoid isolation, he was making efforts to meet other men while on leave, but even in this early period of leave (he was interviewed at 3 weeks into his leave) he was beginning to feel lonely. Parent and baby groups, while giving less intimate interactions than the women reported having while on leave, did serve to help men on leave in 'getting out of the house' and in creating some adult interaction in their days.

The decision to take a leave which so few fathers take up, also had the consequence of isolating participants from their peers. Peter, for example, wrote the following in his diary:

I even lost one of my friends during my time on APL. He thought I was leeching on benefits. I told him I'm just taking the remainders of my wife's Maternity Pay. But he's very conventional and thinks a woman should take care of the kids rather than men. I told him

\footnotetext{
${ }^{6}$ Only Anka reported experiencing similar levels of isolation to the male participants; Anka is a relatively recent migrant to the UK and said she had few friends in London.

${ }^{7}$ Parent and baby playgroup.
} 
I think he's a traditionalist, he got offended and didn't want to be my friend anymore. I don't know. Feels silly that someone cannot be friends with you because you want to spend time with your son. Peter, Sales assistant, 31 (6 months leave)

This was the most extreme example of a hostile reaction. Others reported that friends or family appeared to react defensively on hearing about the couple's decision to take APL, for example by listing the reasons why that would not have been possible for them, or mothers saying that they would not have liked their husband to 'steal' her leave in that way. McKay and Doucet (2010) reported similar findings in Canada amongst couples discussing the take-up of gender-neutral parental leave. Their participants also understood the leave as properly the mothers and men reported avoiding leave so as not to 'take away' their partner's opportunity to take it. The transferral policy in the UK is likely to compound the notion of the leave as the woman's, and may in part explain the very low take-up.

However, some couples reported a broadly positive response from peers Charlotte and Arthur, for example, said that they knew of other couples who had taken APL and that their peers were very supportive and some planned to do the same in the future. Arthur's best friend is also a full-time stay-at-home Dad. Some couples reported that colleagues or friends were surprised at their decision to use APL (often because they had never heard of it) but were at the same time very supportive and positive. Whatever the reactions though, either positive or negative, actors in their social networks had a tendency to 'other' the couple, which some enjoyed and others less so. This 'othering' process, was not described as a necessarily inferiorising process (c.f. Jensen 2011), but as being positioned as different or apart from the majority.

\subsubsection{Perceived Consequences of Taking Leave}

\section{A Closer Bond and a More Competent Father}

The fathers and mothers reported fathers' increased confidence and competence in taking care of their baby, and a strengthened bond between father and child as the primary consequence of APL. Simon, for example, enthusiastically described how having the sole responsibility of care during APL had been 'really beneficial' for his relationship with his son:

Interviewer: So having taken more responsibility - in what way does it affect your relationship with [son]?

Simon: Well just because I know, like, I can just read him really well. Like I knew he was doing a poo earlier on, I saw half an hour ago he was getting quite tired and it's just you know what he's up to and what he's thinking, or how he's feeling. And also the way he responds to me when, I like, come home from work, he's generally quite happy. So we have this like - I don't know, quite a strong bond, which I don't think would have happened in quite the same way if . I hadn't have been off with him. Just you know, trying to keep him from being grumpy before bed time, things like that. Simon, Lawyer, 35 (3 months leave) 


\section{Likewise, Jason reflected:}

Now he and I have really got that bond (that son and mother developed). More so now, I feel like he's my little buddy and we're a little team and just spend our days together and do stuff together. It's kind of like almost like you're best mates. But I didn't have that beforehand because we weren't spending that much time together. Jason, Charity worker, 34 (9 months leave)

Kylie, Jason's wife, also discussed her observations of Jason's increased confidence. Initially, she remarks, he could not take any advice from her as he considered it a criticism of his parenting. Now, he listens to her, but states his own opinion. This gaining of independence or emergence of co-parenting was a common theme across the accounts. John's wife Evie, remarked 'there was a point I think not very long into John starting paternity leave where he just stopped asking me [laughs] "what should I do?" She went on to describe that before APL, although John had been very actively involved in taking care of their daughter, she had always felt that she was positioned as the 'expert', but after his APL both reported that John was far more independent in taking care of their daughter.

\section{Consequences for Career}

Despite the rarity of taking leave alone in the UK, none of the fathers reported a negative reaction from their workplace. Even though in all cases the men were the first in their workplace to take APL, they did not in general anticipate or experience any problems, which they attributed to other (male) employees' previous use of flexible working. For example, Arthur said:

Interviewer: Okay, yeah at the last interview you hadn't actually told your work that you wanted to go on APL. So I was just wondering how that went?

Arthur: Yeah, it went well. [...] [My line manager] was like initially 'oh no, how am I going to cope with just me?' But yeah, he had a chat with his line manager and it was absolutely fine. I think, as I said to you, he was familiar with the whole -- he has three children himself, he took a year out himself, before APL was an option. [...] But really I wasn't too worried because I know [my workplace] is the sort of place where I think they have an attitude towards -- there are policies in place about this, it's not -- I think if I'd been in the private sector it might have been -- there might have been less kind of an attitude of -- I don't know. Arthur, Librarian, 47 (3 months leave)

Previous research suggests that fathers in the public sector, in larger firms and in female-dominated workplaces, are more likely than those in private firms, smaller firms or male-dominated workplaces to take leave (Bygren and Duvander 2006; Chanfreau et al. 2011). Two of the fathers work in the public sector (a university and a library) and one in a female dominated charity. Simon works in a Swedish company which he argued was more 'used to' the idea of men taking extended leave. Only Peter worked in a large private retail store which had, as far as he was aware, little experience of men taking leave, but nonetheless he reported no adverse reaction.

When asked about any longer term impact on their careers, fathers reported that it was too early to tell, but they felt that the time they had taken (on average about 5 months for this group of fathers) was unlikely to have a major impact, or that the 
impact was unlikely to be more than their wife was experiencing. Having a partner who earns a similar amount, or more, is also more likely to take the pressure off fathers as breadwinners. Either way, Simon, Arthur and Jason all reported that they had been looking forward to taking time out from their jobs, and that in fact this was part of their motivation to take APL. For Simon, a lawyer, this was a means to do something different for a while and to take up other interests (such as in home decoration). For Arthur and Jason, a librarian and a charity worker respectively, taking leave alone was an opportunity to distance themselves from work that they were not enjoying. Peter did not mention this motivation, but also appeared to have a low attachment to his current work. From this group of fathers John, a university Lecturer, was really the only father who appeared to enjoy his work. Thus, it may be that fathers who are less attached to their work are more likely to take leave and/or are less concerned about the potential impacts of leave on their work. These findings reflect those of Gatrell and colleagues (2015) who conducted a large qualitative study with fathers in the UK. They observed a tendency amongst some men to prioritise the care of their children over paid work, forgoing opportunities for promotion so as to facilitate this orientation.

\subsection{Conclusions}

This chapter has presented findings from a study of fathers taking leave alone in a normative context of active fatherhood set against weak formal institutional support. In Britain individual entitlements to paid paternity leave are still minimal in duration and lacking in generosity in terms of income replacement. Britain's 52 weeks is one of the longest maternity leaves in Europe with the first 6 weeks comparatively well paid and the remaining time to 39 weeks paid at low income replacement levels. Similarly, an 18 week parental leave provision through the EU Directive, whilst available as an individual entitlement to both fathers and mothers, is unpaid and not culturally promoted at a national level. In this societal context fathers of the current study were only able to take extended leave with their baby through a recent flexibility, titled Additional Paternity Leave, introduced to allow mothers to transfer maternity leave to partners.

In the chapter we have concentrated on the study fathers' motivations to take APL, their experiences and the perceived consequences for work and family life. The couple centred design of the study, with its theoretical focus on the intersections of intimacy, gender and equality, has illuminated how private and public gendered positions are negotiated in this ambiguous societal context. Notions of 'fairness' within couples strongly shaped their narrations around leave, whether this was fairness of access to leave or access to more time in employment (through men taking on part of her leave). Nonetheless, interview accounts portray how, despite men's lack of formal individual entitlement, they tended to be positioned as the decision makers in taking leave - 'it's his choice'. In turn, women's structural agency, both in terms of economic status as higher earners and as holders of the 
policy entitlement, was often underplayed. Drawing on Hochschild‘s (2003) writings on the 'gift economy' of couples, we suggest that couple negotiations around APL can be conceptualised as a form of gift exchange. However, the nature of the gift and the power differentials of donator and recipient are imbued with tension. Women portrayed leave as an 'opportunity' to their partners, but disclosed privately their concerns that their 'offer' may not be taken up and ambivalence about their gratitude when he did. Although a norm of caring fatherhood is endorsed in British culture, so too is an expectation of work commitment, reinforced by rather weak institutional support when men become parents and comparatively high levels of paternal working hours (Connolly et al. 2013). In this context, the gift of time to care, even with job protection, carries gendered and economic risks to men, with a potential to challenge continuing aspects of masculine identity and status. The gratitude displayed by mothers in the relational gift exchange, may be part of a deferential tactic by a more subordinate status carrier to position men as the deciders and more powerful (Bell and Newby 1976; Backett 1982). The pattern of gratitude display being more evident in the couple interviews than in the individual interviews supports this hypothesis and resonates with Fox's (2009) study of first-time couples becoming parents in Canada. Fox argues that the gratitude and praise given by women to men when he performs care, is a form of "care" that she gives to him, and creates further inequalities as the mother takes extra care of the father in exchange for him taking some care of the child.

In terms of the observational data and reports from fathers themselves, there was evidence of increased competency and independence in the care of babies and for men's growing connection to infant life, described also by mothers about the fathers. These British findings, albeit from a small case study, support the emerging body of international research about the experiences and impact of being a father on leave alone (e.g. Brandth and Kvande 2002; Wall 2014). Future research will need to extend sampling strategies to represent a wider range of British fathers in the workplace to explore the generalizability of our findings. More research is also needed to see how sustainable these parenting practices are and to examine the impact of future life events, particularly a second child, especially since not all of the fathers stated a wish to take a period of leave alone with a second child. As far as the broader policy context is concerned, clearly greater shared caring of young children by British parents will be better realised when leave policy design moves beyond a maternal template and offers fathers, as well as mothers, individual non-transferable well-paid entitlements to care.

\section{References}

Asher, R. (2012). Shattered: Modern motherhood and the illusion of equality. London: Vintage.

Backett, K. (1982). Mothers and fathers: A study of the development and negotiation of parental behaviour. London: Macmillan.

Bell, C., \& Newby, H. (1976). Husbands and wives: The dynamics of the deferential dialectic. In D. Barker \& S. Allen (Eds.), Dependence and exploitation in work and marriage. London: Longman. 
Brandth, B., \& Kvande, E. (2002). Reflexive fathers: Negotiating parental leave and working life. Gender, Work and Organization, 9(2), 186-203.

Brannen, J., Moss, P., \& Mooney, A. (2004). Working and caring over the twentieth century: Change and continuity in four generation families. London: Palgrave.

Bygren, M., \& Duvander, A. Z. (2006). Parents workplace situation and fathers' parental leave use. Journal of Marriage and the Family, 68, 363-372.

Chanfreau, J., Gowland, S., Lancaster, Z., Poole, E., Tipping, S., \& Toomse, M. (2011). Maternity and paternity rights and women returners survey 2009/2010 (Department of Work and Pensions Research Report No 777). Available at: http://research.dwp.gov.uk/asd/asd5/rrs-index.asp

Charmaz, K. (2006). Constructing grounded theory. A practical guide through qualitative analysis. London: Sage.

Collier, R., \& Sheldon, S. (2008). Fragmenting fatherhood: A socio-legal approach. Oxford: Hart Publishing.

Connolly, S., Aldrich, M., O'Brien, M., Speight, S., \& Poole, E. (2013) Fathers and work (ESRC Briefing paper). Available from http://www.modernfatherhood.org/wp-content/ uploads/2013/06/Fathers-and-work.pdf

Cornish, F. (2013). Additional paternity leave: Real-life experiences of an evolving paternity leave system in the UK. MSc thesis, LSE.

Cowan, P., \& Cowan, C. (2000). When partners become parents. New Brunswick: Erlbaum.

Fox, B. (2009). When couples become parents: The creation of gender in the transition to parenthood. Toronto: University of Toronto Press.

Gabb, J. (2008). Researching intimacy in families. Basingstoke/New York: Palgrave Macmillan.

Gatrell, C. J., Burnett, S. B., Cooper, C. L., \& Sparrow, P. (2014). Parents, perceptions and belonging: Exploring flexible working among UK fathers and mothers. British Journal of Management, 25(3), 473-487.

Gatrell, C., Burnett, S., Cooper, C., \& Sparrow, P. (2015). The price of love: The prioritisation of childcare and income earning among UK fathers. Families, Relationships and Societies, 4(2), 225-238.

Gordon, H., \& Szram, J. (2013). Paternity leave experiences of NHS doctors. Clinical Medicine, $13(5), 426-430$.

Gregory, A., \& Milner, S. (2008). Fatherhood regimes and father involvement in France and the UK. Community Work and Family, 11(1), 61-84.

Gregory, A., \& Milner, S. (2011). Fathers and work-life balance in France and the UK: Policy and practice. International Journal of Sociology and Social Policy, 31(1), 34-52.

Guardian. (2010). Fathers to get six months' paternity leave. Retrieved January 28, from http:// www.theguardian.com/money/2010/jan/28/fathers-six-months-paternity-leave

Haas, L., Allard, K., \& Hwang, P. (2002). The impact of organizational culture on men's use of parental leave in Sweden. Community, Work and Family, 5(3), 319-342.

HM Government. (2002). Employment act. Available at: http://www.legislation.gov.uk/ ukpga/2002/22/contents

HM Government. (2010). Additional paternity leave impact assessment. Available at: http://www. legislation.gov.uk/uksi/2010/1055/impacts/2010/32

HM Government. (2015). Paternity pay and leave. Available at: https://www.gov.uk/paternitypay-leave/pay

Hochschild, A. R. (2003). The managed heart: The commercialization of human feeling. Berkeley, CA: University of California Press.

Jamieson, L. (2012). Intimacy as a concept: Explaining social change in the context of globalisation or another form of ethnocentrism. Sociological Research Online, 16(4), 15.

Jensen, S. Q. (2011). Othering, identity formation and agency. Qualitative Studies, 2(2), 63-78.

Koslowski, S. (2011). Working fathers in Europe: Earning and caring. European Sociological Review, 27(2), 230-245.

Koslowski, A. \& Williams, D. (2007). Father Friendly Legislation and paternal time across Western Europe. Journal of Comparative Policy Analysis, 9(3), 175-192. 
Lamb, M. E. (Ed.). (1976). The role of the father in child development. NewYork, NY: Wiley.

McKay, L., \& Doucet, A. (2010). "Without taking away her leave": A Canadian case study of couples' decisions on fathers' use of paid leave. Fathering, 8(3), 300-320.

McKee, L., \& O’Brien, M. (Eds.). (1982). The father figure. London: Tavistock.

Moss, P., \& Deven, F. (2006). Leave policies and research: A cross-national overview. Marriage \& Family Review, 39(3/4), 255-285. doi:10.1300/J002v39n03_03.

Moss, P. (Ed). (2014). International review of leave policies and related research. Available at: http://www.leavenetwork.org/

O'Brien, M. (2009). Fathers, parental leave policies and infant quality of life: International perspectives and policy impact. The Annals of the American Academy of Political \& Social Science, 624, 190-213.

O’Brien, M., Moss, P., Koslowski, A., \& Daly, M. (2014). United Kingdom country note. In P. Moss (Ed.), International review of leave policies and research. Available at: http://www. leavenetwork.org/lp_and_r_reports/

ONS. (2015, April-June). Analysis of labour force survey estimates of people in employment reporting a zero-hours contract. London: Office of National Statistics.

Pahl, J. (1989). Money and marriage. London: Macmillan Education Ltd.

QSR International. (2012). NVIVO 10.

Rochlen, A., McKelley, R., \& Whittaker, T. (2010). Stay-at-home fathers' reasons for entering the role and stigma experiences: A preliminary report. Psychology of Men \& Masculinity, 11(4), 279-285.

Twamley, K. (2012). Gender relations among Indian couples in the UK and India: Ideals of equality and realities of inequality. Sociological Research Online, 17(4).

Wall, K. (2014). Fathers on leave alone: Does it make a difference to their lives? Fathering, 12(2), 196-210.

World Economic Forum. (2014). The global gender gap report 2014. Geneva, Switzerland.

Yarwood, G. (2011). The pick and mix of fathering identities. Fathering, 9(2), 150-168.

Open Access This chapter is licensed under the terms of the Creative Commons AttributionNonCommercial 2.5 License (http://creativecommons.org/licenses/by-nc/2.5/), which permits any noncommercial use, sharing, adaptation, distribution and reproduction in any medium or format, as long as you give appropriate credit to the original author(s) and the source, provide a link to the Creative Commons license and indicate if changes were made.

The images or other third party material in this chapter are included in the chapter's Creative Commons license, unless indicated otherwise in a credit line to the material. If material is not included in the chapter's Creative Commons license and your intended use is not permitted by statutory regulation or exceeds the permitted use, you will need to obtain permission directly from the copyright holder.

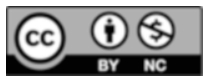

